\title{
IMPROVED ADSORPTION-DESORPTION EXTRACTION APPLIED TO THE PARTIAL CHARACTERIZATION OF THE ANTILISTERIAL BACTERIOCIN PRODUCED BY CARNOBACTERIUM MALTAROMATICUM C2
}

\author{
Tulini, F. L.; De Martinis, E.C.P.*
}

\begin{abstract}
Departamento de Análises Clínicas, Toxicológicas e Bromatológicas, Faculdade de Ciências Farmacêuticas de Ribeirão Preto, Universidade de São Paulo, Brasil.
\end{abstract}

Submitted: November 19, 2008; Returned to authors for corrections: February 10, 2009; Approved: November 07, 2009.

\begin{abstract}
Bacteriocins are ribosomally produced peptides useful for food biopreservation. An improved adsorptiondesorption process is proposed for the partial purification of the bacteriocin produced by the fish isolate Carnobacterium maltaromaticum C2. Analyzis of extract by SDS-PAGE indicated this method may offer an alternative to improve the yield of purification of bacteriocins.
\end{abstract}

Key words: Bacteriocins, LAB, Carnobacterium, SDS-PAGE.

Consumers demand safe, convenient, nutritious and healthy foods, stimulating researches on new antimicrobial agents for food biopreservation. Lactic acid bacteria (LAB) are present as autochthonous microbiota in many fermented products with long history of safe consumption and this group of bacteria can ribosomally synthesize antimicrobial peptides named bacteriocins, which present potential use as biopreservatives $(7,12)$. Bacteriocins of $\mathrm{LAB}$ are cationic, hydrophobic and present high isoeletric point that facilitates the extraction from the producers cells, depending on $\mathrm{pH}$ (9). Bacterial cell surface presents phospholipids with anionic characteristics at neutral and acid $\mathrm{pH}$ and can be used as a matrix for the initial purification of LAB bacteriocins, which can be further purified using chromatographic processes based on hydrophobic interaction, cationic exchange and reversephase chromatography $(4,12)$. Yang et al. (16) described a method for purification of bacteriocins based on the adjustment of the $\mathrm{pH}$ of broth cultures and used the own bacterial cells as adsorbent material. Besides, Todorov et al. (15) and Khouiti et al. (8) observed that the adsorption of bacteriocins to the producer cells and other surfaces may be influenced by compounds such as surfactants and salts $(6,15)$.
The common features of the bacteriocins produced by the genus Carnobacterium are low molecular weight (4.2 to $5 \mathrm{kDa}$ ) and high isoelectric point, between 9 and 10 (4). The strain Carnobacterium piscicola $\mathrm{C} 2$, isolated by from cold-smoked, vacuum-packed surubim fish, produces a bacteriocin that inhibits the growth of L. monocytogenes in smoked fish juices and in surubim homogenate at $10^{\circ} \mathrm{C}$ (1). Mora et al. (11) have proposed the re-classification of Carnobacterium piscicola as Carnobacterium maltaromaticum due to DNA-DNA relatedness. In the present work, the bacteriocin of Carnobacterium maltaromaticum $\mathrm{C} 2$ (previously referred as Carnobacterium piscicola $\mathrm{C} 2$ ) was partially purified and characterized and a two-steps adsorption-desorption extraction was proposed, which may contribute for obtaining improved bacteriocin preparation for food applications.

C. maltaromaticum $\mathrm{C} 2$ and L. monocytogenes IAL 633 were used in this study and maintained in Brain Heart Infusion broth (BHI, Oxoid, UK), cryoprotected with $20 \%$ glycerol (Synth, Brazil) at $-70^{\circ} \mathrm{C}$. Working cultures were prepared in BHI broth incubated at $20^{\circ} \mathrm{C}$ for C. maltaromaticum $\mathrm{C} 2$ and at $37^{\circ} \mathrm{C}$ for L. monocytogenes IAL633.

Bacteriocin extraction was done in a two-steps approach, 
using a modification to the method proposed by D'Angelis et al. (5), using L. monocytogenes as indicator strain for monitoring antimicrobial activity. Two liters of culture of $C$. maltaromaticum $\mathrm{C} 2$ was obtained in $\mathrm{BHI}$ broth at $20^{\circ} \mathrm{C} / 18 \mathrm{~h}$ and the $\mathrm{pH}$ was adjusted to 6.0. Cells were harvested at $6,048 \times \mathrm{xg} / 20$ minutes $/ 4^{\circ} \mathrm{C}$ (Sorvall RC 5C Plus, USA) and the cell pellet was washed twice with phosphate buffer $5 \mathrm{mM}$ pH 6.0 . The cell pellet was resuspended in $50 \mathrm{ml}$ of $0.1 \mathrm{M} \mathrm{NaCl}$ solution $\mathrm{pH} 1.5$ and kept at $4^{\circ} \mathrm{C} / 1 \mathrm{~h}$ under agitation with a magnetic stirrer. The suspension was centrifuged at 10,080xg/15 minutes $/ 4^{\circ} \mathrm{C}$ (Sorvall RC 5C Plus) and the supernatant was collected. The remaining cell pellet was added again to the initial supernatant of culture broth, and the extraction was repeated. The cell-free supernatants obtained after the extractions were combined, dialyzed against distilled water in $1 \mathrm{KDa}$ exclusion membrane (Spectra/Por ${ }^{\circledR}$ Biotech Cellulose Ester Dialysis Membrane, Spectrum, USA) and freeze-dried (VirTis Lyophilizer, USA). Aliquots of the supernatants were taken after each step for quantification of bacteriocin activity, according to Mayr-Harting et al. (10). An extraction as described by D'Angelis et al. (5) was carried out for comparison purposes. Protein contents of dried powders were determined by the Bradford method (2) adapted for microassay.

Bacteriocin extracts were analyzed by SDS-PAGE, with stacking gel of $4 \%$ and resolving gel of $16 \%$, using all chemicals from Bio-Agency (São Paulo, Brazil). Electrophoresis was done at 10mA/4h (Mini-Protean Cell 3, BioRad, USA), with trisglycin buffer solution and pre-stained low molecular weight markers $(2.5$ and $45 \mathrm{kDa}$, Amersham Biosciences, U.K.).

Half of the gel was silver stained (Protein Silver Staining Kit, Amersham Biosciences, Sweden) and half was fixed with a solution of ethanol (40\%) and acetic acid (10\%) for 30 minutes. The fixed gel was washed under running distilled water for 2 hours and placed on a BHI agar plate. The gel was overlayed with $7 \mathrm{ml}$ of soft BHI agar $(0.8 \%)$ seeded with $L$. monocytogenes (ca. $10^{6} \mathrm{CFU} / \mathrm{ml}$ ). After diffusion for $18 \mathrm{~h}$ at $4^{\circ} \mathrm{C}$ it was incubated for $8-12 \mathrm{~h}$ at $37^{\circ} \mathrm{C}(5)$ and the resulting gel was documented with a digital camera (Sony Cyber-Shot W35).

Bacteriocin activity obtained from C. maltaromaticum $\mathrm{C} 2$ during the purification steps are shown in Table 1. The extraction procedure used in this work resulted in $7.5 \%$ yield, compared to $2.5 \%$ of a previous reported extraction (5), with $28.0 \mathrm{mg}$ of dry powder containg $1.03 \%$ of proteins, and a specific activity of $622,477 \mathrm{AU} / \mathrm{mg}$ (Table 1). The use of the two-steps approach resulted in more effective bacteriocin purification than other protocols based on adsorptiondesorption of bacteriocins to producers cells $(5,16)$. This fact is related to the reversible capacity of bacteriocins to adsorb and desorb from the producers cells. Results indicate that the bacterial cells may be used to extract bacteriocins from the culture broth at least twice. Table 1 shows that not all the bacteriocin present in the initial broth can be adsorbed by the producers cells, likely due to saturation of the binding sites of the cell membrane. It also shows that not all the bacteriocin molecules desorbed at the end of extraction, indicating that some adjustments can still increase the final yield. Yang et al. (16) obtained good results for the acid extraction applied for purification of pediocin $\mathrm{AcH}$ (106.7\%), nisin (93.3\%), sakacin A (44.3\%) and leuconocin Lcm1 (96.2\%), but in this study with C. maltaromaticum $\mathrm{C} 2$ that method resulted in low yield. Even considering that it is difficult to compare interlaboratory results of bacteriocin purification due to differences in definitions of arbitrary units, levels of bacteriocin produced in the initial broth, variation in the number of cells and intrinsic cell capacity of adsorption, the present results indicate that the two-steps extraction is advantageous as larger amounts of bacteriocins can be obtained.

SDS-PAGE of the extract obtained with the double acid extraction revealed with the bioindicator L. monocytogenes (Figure 1B) presented a band with antimicrobial activity, revealed by silver staining (Figure 1A). This band corresponded to a compound molecular weight between 3.5 and $6.5 \mathrm{KDa}$. Contaminant proteins were also detected in the silver stained gel (Figure 1A), indicating that further purification is required for the complete characterization of the 
antimicrobial peptide. Other studies on the purification of antimicrobials produced by other Carnobacterium species revealed peptides of molecular weight similar to the bacteriocin from C. maltaromaticum C2, with 4,635 Da for carnocin UI49 to $6 \mathrm{KDa}$ for BLIS $213(8,14)$.
In conclusion, the proposed two-steps extraction procedure offers a good alternative for improved recovery of $C$. maltaromaticum $\mathrm{C} 2$ bacteriocin from culture broth and can contribute for successful application of this isolate in food biopreservation.

Table 1. Bacteriocin activity and final yield during the traditional and improved acid extraction proposed for the partial purification of the bacteriocin produced by $C$. maltaromaticum $\mathrm{C} 2$. The two extraction of the improved method were made from the same culture broth, in sequence.

\section{TRADITIONAL EXTRACTION}

\begin{tabular}{lcc}
\hline Material & Average activity (AU/mL) & Total activity (AU) \\
\hline Initial broth $(2000 \mathrm{~mL})$ & 320 & 640000 \\
Bacteriocin not adsorbed $(2000 \mathrm{~mL})$ & 160 & 320000 \\
Phosphate buffer pH $6.0(50 \mathrm{~mL})$ & 0 & 0 \\
Dialysed final supernatant $(200 \mathrm{~mL})$ & 80 & \multirow{2}{*}{ Yield } \\
\end{tabular}

\section{IMPROVED ACID EXTRACTION}

\begin{tabular}{|c|c|c|c|}
\hline \multicolumn{2}{|c|}{ Material } & Average activity $(\mathrm{AU} / \mathrm{mL})$ & Total activity (AU) \\
\hline \multicolumn{2}{|c|}{ Initial broth $(2000 \mathrm{~mL})$} & 200 & 400000 \\
\hline & Bacteriocin not adsorbed $(2000 \mathrm{~mL})$ & 200 & 400000 \\
\hline \multirow[t]{3}{*}{ \pm} & Phosphate buffer pH $6.0(50 \mathrm{~mL})$ & 0 & 0 \\
\hline & Final supernatant $(50 \mathrm{~mL})$ & 200 & 10000 \\
\hline & Bacteriocin not adsorbed $(2000 \mathrm{~mL})$ & 100 & 200000 \\
\hline \multirow[t]{2}{*}{$\overrightarrow{\widetilde{E}}$} & Phosphate buffer pH $6.0(50 \mathrm{~mL})$ & 0 & 0 \\
\hline & Final supernatant $(50 \mathrm{~mL})$ & 400 & 20000 \\
\hline \multirow{2}{*}{\multicolumn{2}{|c|}{ Dialysed supernatant (200mL) }} & 150 & 30000 \\
\hline & & & $7.5 \%$ \\
\hline
\end{tabular}

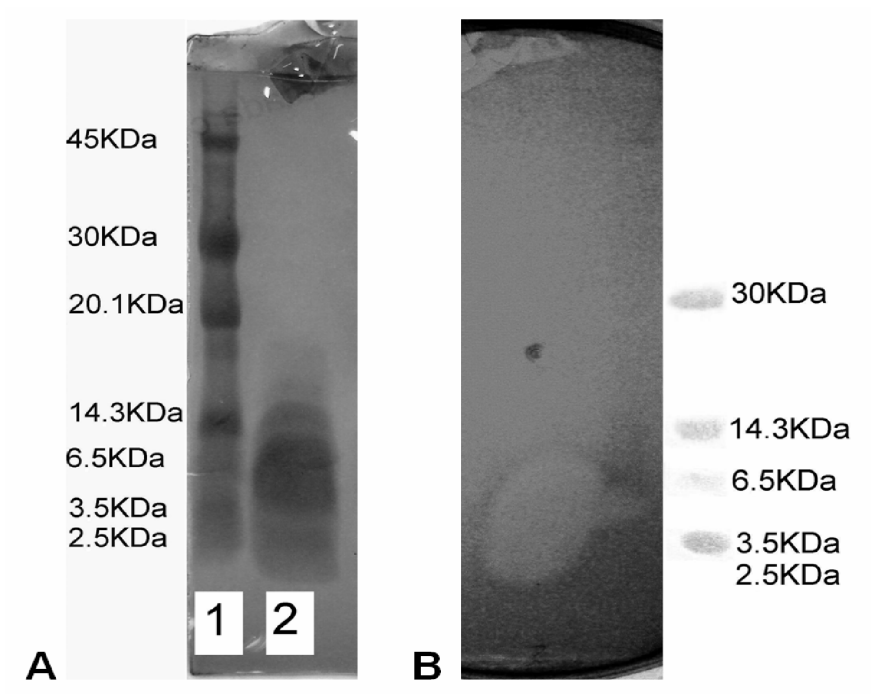

Figure 1. SDS-PAGE analysis of bacteriocin extracts obtained with the two-steps adsorptiondesorption method. A) Silver stained gel. Lane 1: pre-stained low-range molecular marker; lane 2: bacteriocin extract. B) Gel prepared with the bioindicator $L$. monocytogenes. The prestained molecular marker indicates the molecular weight range. 


\section{ACKNOWLEDGEMENTS}

F. L. T. thanks The State of São Paulo Research Foundation (FAPESP) for a scientific initiation fellowship (process \# 07/50236-0). Authors thank Ana Cristina Morseli Polizello (FCFRP - USP) for excellent technical support and Prof. Maria Cristina Nonato, Ph. D. (FCFRP - USP) for helpful discussions.

\section{REFERENCES}

1. Alves, V.F.; De Martinis, E.C.P.; Destro, M.T.; Vogel, B.F.; Gram, L. (2005). Antilisteral activity of a Carnobacterium piscicola isolated from brazilian smoked fish (Surubim [Pseudoplatystoma sp.]) and its activity against a persistent strain of Listeria monocytogenes isolated from surubim. J. Food Prot., 11, 2068-2077.

2. Bradford, M.M. (1976). A rapid and sensitive method for the quantitation of microgram quantities of protein utilizing the principle of protein-dye binding. Anal. Biochem., 72, 248-254.

3. Chen, Y.S.; Yanagida, F.; Srionnual, S. (2007). Characteristics of bacteriocin-like inhibitory substances from dochi-isolated Enterococcus faecium D081821 and D081833. Lett. Appl. Microbiol., 44, 320-325.

4. Cintas, L.M.; Casaus, M.P.; Herranz, C.; Nes, I.F.; Hernández, P.E. (2001). Review: bacteriocins of lactic acid bacteria. Food Science Technology International, 7(4), 281-305.

5. D’Angelis, C.E.M.; Polizello, C.; Nonato, M.C.; Spadaro, A.C.C.; De Martinis, E.C.P. (2008). Purification, characterization and N-terminal amino acid sequencing of sakacin 1, a bacteriocin produced by Lactobacillus sakei 1. J Food Saf, in press.

6. Elegado, F.B.; Kim, W.J.; Kwon, D.Y. (1997). Rapid purification, partial characterization, and antimicrobial spectrum of the bacteriocin, Pediocin AcM, from Pediococcus acidilactici M. Int. J. Food Microbiol., 37, 1-11.
7. Guinane, C.M.; Cotter, P.D.; Hill, C.; Ross, R.P. (2005). Microbial solutions to microbial problems; lactococcal bacteriocins for the control of undesirable biota in food. J. Appl. Microbiol., 98, 1316-1325.

8. Khouiti, Z.; Simon, J.P. (1997). Detection and partial characterization of a bacteriocin produced by Carnobacterium piscicola 213. J. Ind. Microbiol. Biotechnol., 19(1), 28-33.

9. Li, C.; Bai, J.; Li, W.; Cai, Z.; Ouyang, F. (2001). Optimization of conditions for bacteriocin extraction in PEG/salt aqueous two-phase systems using statistical experimental designs. Biotechnol. Prog., 17, 366-368.

10. Mayr-Harting, A.; Hedges, A.J.; Berkeley, R.C.W. (1972). Methods for studying bacteriocins. Methods in Microbiology, 7, 313-342.

11. Mora, D.; Scarpellini, M.; Franzetti, L.; Colombo, S.; Galli, A. (2003). Reclassification of Lactobacillus maltaromicus (Miller et al. 1974) DSM 20342T and DSM 20344 and Carnobacterium piscicola (Collins et al. 1987) DSM 20730T and DSM 20722 as Carnobacterium maltaromaticum comb. nov. Int. J. Syst. Evol. Microbiol., 53, 675-678.

12. Oscariz, J.C.; Pisabarro, A.G. (2001). Classification and mode of action of membrane-active bacteriocins produced by gram-positive bacteria. Int Microbiol., 4, 13-19.

13. Schöbitz, R.; Suazo, V.; Costa, M.; Ciampi, L. (2003). Effects of a bacteriocin-like inhibitory substance from Carnobacterium piscicola against human and salmon isolates of Listeria monocytogenes. Int. J. Food Microbiol., 84, 237-244.

14. Stoffles, G.; Nissen-Meyer, J.; Gudmundsdóttir, S.; Sletten, K.; Holo, H.; Nes, I.F. (1992). Purification and characterization of a new bacteriocin isolated from a Carnobacterium sp. Appl. Environ. Microbiol., 58, 1417 1422.

15. Todorov, S.D.; Dicks, L.M. (2006). Parameters affecting the adsorption of plantaricin 423, a bacteriocin produced by Lactobacillus plantarum 423 isolated from sorghum beer. Biotechnol J, 1, 405-409.

16. Yang, R.; Johnson, M.C.; Ray, B. (1992). Novel method to extract large amount of bacteriocins from lactic acid bacteria. Appl. Environ. Microbiol, 58(10), 3335-3359. 